\title{
Laboratory diagnosis of invasive aspergillosis
}

\author{
WW Hope, TJ Walsh, D W Denning
}

Invasive aspergillosis occurs in a wide range of clinical scenarios, is protean in its manifestations, and is still associated with an unacceptably high mortality rate. Early diagnosis is critical to a favourable outcome, but is difficult to achieve with current methods. Deep tissue diagnostic specimens are often difficult to obtain from critically ill patients. Newer antifungal agents exhibit differential mould activity, thus increasing the importance of establishing a specific diagnosis of invasive aspergillosis. For these reasons, a range of alternate diagnostic strategies have been investigated. Most investigative efforts have focused on molecular and serological diagnostic techniques. The detection of metabolites produced by Aspergillus spp and a range of aspergillus-specific antibodies represent additional, but relatively underused, diagnostic avenues. The detection of galactomannan has been incorporated into diagnostic criteria for invasive aspergillosis, reflecting an increased understanding of the performance, utility, and limitations of this technique. Measurement of (1,3)- $\beta$-D glucan in blood may be useful as a preliminary screening tool for invasive aspergillosis, despite the fact that this antigen can be detected in a number of other fungi. There have been extensive efforts directed toward the detection of Aspergillus spp DNA, but a lack of technical standardisation and relatively poor understanding of DNA release and kinetics continues to hamper the broad applicability of this technique. This review considers the application, utility, and limitations of the currently available and investigational diagnostic modalities for invasive aspergillosis.

\section{Introduction}

Aspergillus spp are ubiquitous opportunistic moulds that cause both allergic and invasive syndromes. The genus comprises approximately 180 species, of which 33 have been associated with human disease. Most infections are caused by Aspergillus fumigatus, Aspergillus flavus, Aspergillus terreus, and Aspergillus niger, ${ }^{1}$ less commonly, Aspergillus nidulans can be implicated as the causative pathogen, especially in the setting of chronic granulomatous disease. ${ }^{2}$

An accurate diagnosis of invasive aspergillosis is important for clinical reasons; an earlier diagnosis is associated with improved patient survival ${ }^{3}$ and tests with a high negative predictive value may allow expensive and potentially toxic antifungal drugs to be withheld. New drugs-eg, voriconazole-exhibit differential mould activity; the ability to specifically exploit their antiaspergillus properties requires a rapid and accurate laboratory diagnosis. The epidemiology of invasive aspergillosis is changing; invasive disease is increasingly observed in the non-neutropenic phase of haematopoietic stem cell transplantation ${ }^{46}$ and in nonclassic settings such as critically ill patients in intensive care units. ' Aspergillus spp other than A fumigatus-some of which demonstrate inherent resistance to antifungal drugs-are increasingly recognised. ${ }^{8-10}$ An international collaborative effort recently produced standardised definitions for invasive fungal infections. ${ }^{11}$ Thus, a review of the diagnostic modalities and their use in establishing a diagnosis of invasive aspergillosis is timely.

\section{Diagnostic tools}

\section{Direct techniques}

The advantages of direct techniques over culture include superior sensitivity and a relatively rapid turn around time. The principal disadvantage is the inability to definitively distinguish other filamentous fungi (eg,

Penicillium spp and Scedosporium spp) or implicate Aspergillus spp as the causative pathogen in circumstances in which there are atypical or non-specific morphological features. This disadvantage may compromise diagnostic accuracy and hence estimates of therapeutic efficacy if patients are recruited to clinical trials solely on the basis of hyphae that resemble Aspergillus spp. Within tissue sections, Aspergillus spp typically appear as slender septate hyphae that exhibit angular dichotomous branching (figure 1).
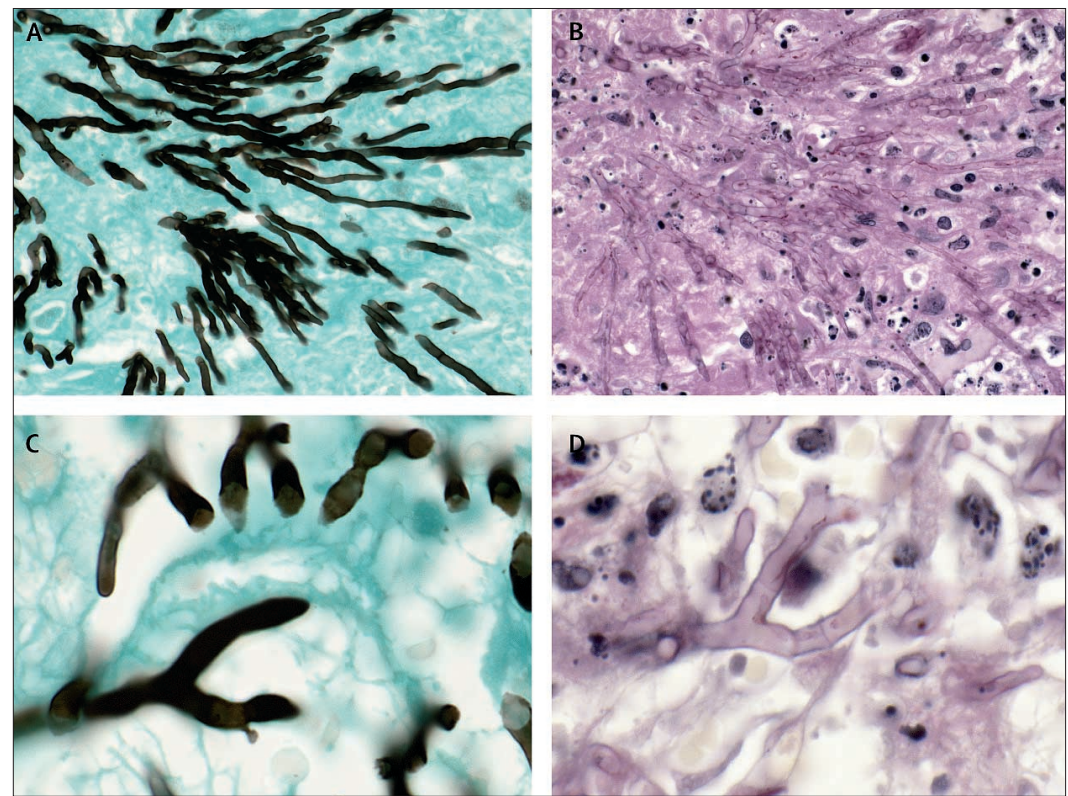

ancet Infect Dis 2005 5: 609-22

DWD and WWH are at the School of Medicine, University of Manchester and Wythenshawe Hospital, Manchester, UK; TJW is at the Pediatric Oncology Branch, National Cancer Institute, National Institutes of Health Bethesda, MD, USA. WWH is also at the Pediatric Oncology Branch, National Cancer Institute.

Correspondence to:

Professor David W Denning,

Education and Research Centre, Wythenshawe Hospital,

Southmoor Road, Manchester M23 9LT, UK

Tel +44 (0)1612915811;

$\mathrm{fax}+44(0) 1612915806$ ddenning@manchester.ac.uk

Figure 1: The appearance of Aspergillus spp in histological sections

(A) Gomori methanamine silver (GMS) stain of rabbit lung in experimental invasive pulmonary aspergillosis (magnification $\times 400$ ). (B) A similar section stained with periodic acid-Schiff (PAS) (magnification x400). (C) and (D) show acute angle dichotomous branching, which is typical of Aspergillus spp (magnification x630). The GMS sections demonstrate the prominent staining and stark appearance of hyphae. By contrast, with PAS there is preservation of background histological detail and hyphal morphology, but hyphae are less conspicuous against the background. 
Wet mounts, potassium hydroxide preparations, and use of routine stains

All specimens obtained in scenarios in which fungi are possible aetiological agents should be subject to a series of routine direct procedures; these procedures may vary according to the specimen, degree of clinical urgency, and the individual laboratory. Specimens may be examined as a wet mount preparation with or without the addition of $10 \%$ potassium hydroxide, which aids in the visualisation of hyphal elements through the partial digestion and clearing of proteinaceous material while leaving the fungal cell wall intact. ${ }^{12}$ Subsequently, a smear is made on a slide, fixed and subjected to a variety of staining procedures. A Gram stain should be done as a matter of routine, but cytological stains (eg, Papanicolaou stain), fungal stains, and fluorescent stains may improve sensitivity.

\section{Fungal stains}

Fungal-specific stains should be applied in all cases in which invasive aspergillosis is considered a diagnostic possibility. ${ }^{13}$ Hyphal elements are stained with haematoxylin and eosin, although they may be difficult to visualise if sparse, fragmented, or present in the setting of substantial tissue necrosis. Fungal-specific stains-eg, Gomori's methenamine silver stain (GMS) and periodic acid-Schiff (PAS)—can be applied to histological sections and smears (figure 1). On occasion, GMS is referred to as Grocott's stain or the GrocottGomori silver stain-Robert Grocott demonstrated that GMS, which was initially designed as a stain for glycogen and mucin, also readily stained fungal elements. $^{14}$ PAS has the advantage of providing a counter stain that reveals the background host cellular detail, tissue architecture, and inflammatory response. By contrast, the GMS counter stain removes the fine details of background host cells and tissues, but provides a more sensitive stain for detecting small fragments of cell wall that may be otherwise obscured by surrounding tissue elements. Thus, for detection of hyphal elements, the use of the GMS stain may be more sensitive; whereas PAS provides more of the cellular detail and architecture that may be of help in establishing relations between the fungus and other elements of tissue. This may be important in defining the individual aspergillus-related syndromes that vary according to the immunological status of the host. In this regard, GMS and PAS are complementary.

\section{Fluorescent techniques}

Fluorescent dyes-eg, Calcofluor white, Uvitex 2B, and Blankophor-are water-soluble colourless dyes that selectively bind to beta-glycosidically linked polysee saccharides within fungal cell walls. They are not specific http://www.aspergillus.man.ac.uk http://www.mycology. adelaide.edu.au and http://www.doctorfungus.org paraffin-embedded tissue, and other fresh clinical specimens-eg, bronchoalveolar lavage fluid (BAL) or corneal scrapings. ${ }^{15,16}$

\section{Immunohistochemistry, immunofluorescence, and in-situ hybridisation}

Immunohistochemistry (using the monoclonal antibody WF-AF- $1^{17}$ or EB-A $1^{18,19}$ ), immunofluorescence, ${ }^{20}$ and insitu hybridisation ${ }^{21,22}$ have been studied as diagnostic modalities. Collectively, these techniques have the potential to provide genus and species specific data, which may be important to improve diagnostic certainty when hyphae are seen invading tissue, but cultures or other adjunctive diagnostic data are negative. The availability of these modalities in routine clinical microbiology laboratories is variable.

\section{Culture}

A culture yielding Aspergillus spp, in addition to enabling a diagnosis of invasive aspergillosis, may further define therapeutic options via susceptibility testing or the isolation of a species possessing inherent antifungal resistance; examples of the latter include $A$ terreus and A nidulans, which are both resistant to amphotericin B. ${ }^{10,23}$ The main disadvantage of culture is that it is relatively slow (the process takes days), is relatively insensitive, ${ }^{24}$ and requires specialised expertise for species determination.

In common with other pathogenic fungi, the ability to grow at $37^{\circ} \mathrm{C}$ distinguishes Aspergillus spp from other nonpathogenic environmental moulds. Aspergillus spp can be recovered on most routine solid and liquid microbiological media (eg, blood agar, chocolate agar, brain heart infusion broth). A fungal-specific mediumeg, Sabouraud dextrose agar-should be included at the time of initial specimen set-up in clinical scenarios in which Aspergillus spp (or other moulds) are considered possible pathogens, because of superior yield. ${ }^{25}$ The addition of antibiotics-eg, chloramphenicol and gentamicin-to the medium is required for the recovery of Aspergillus spp from specimens obtained from nonsterile sites, since they prevent bacterial overgrowth. Cycloheximide, a eukaryotic protein synthesis inhibitor, is frequently added to fungal media to inhibit the overgrowth of cultures by non-pathogenic environmental moulds; however, on occasion, cycloheximide may inhibit the growth of Aspergillus spp. ${ }^{26}$

The identity of a laboratory isolate can often be inferred on the basis of colonial morphology and colour. Definitive identification, however, is dependent on a detailed inspection of conidial morphology and ontogeny and requires a microscopic examination of a simple teased preparation or a slide culture (a procedure in which sporulation is induced and the relevant diagnostic features are visualised on the under-surface of a cover-slip). The appearance and diagnostic features of individual species is beyond the scope of this review and readers are referred to definitive texts, ${ }^{27}$ useful guides, ${ }^{28}$ and excellent websites. 
Several additional issues pertaining to culture require emphasis. First, the growth characteristics and morphological appearances of Aspergillus spp are protean and in some circumstances quite atypical; in this regard, Aspergillus spp are great mimics and should always be included in the list of diagnostic possibilities for an unidentified mould. Second, at least on occasion, sporulation may be difficult or impossible to induce, ${ }^{29}$ and other modalities must be used for the purposes of identification. In this circumstance, molecular techniques are perhaps best placed to enable rapid and accurate identification.

\section{Serological techniques \\ Galactomannan}

Galactomannan is a heat-stable heteropolysaccharide present in the cell wall of most Aspergillus and Penicillium species. $^{30}$ The molecule is comprised of a nonimmunogenic mannan core with immunoreactive sidechains of varying lengths containing galactofuranosyl units. ${ }^{30}$ The composition of galactomannan varies between genera and strains, as well as the strain and conditions used for its production, extraction, and purification. ${ }^{30}$ There are two commercial assays for the detection of galactomannan-the Pastorex kit (Sanofi Diagnostics Pasteur,Marnes-La-Coquette, France) and Platelia ELISA (BioRad, Marnes-La-Coquette, France). Pastorex is now rarely used, while Platelia has been available in Europe for approximately 10 years and has recently been licensed in the USA. There has been a progressive increase in the understanding of the diagnostic utility of galactomannan to a point that has enabled its incorporation into diagnostic criteria. ${ }^{11}$ However, galactomannan testing is not universally available to clinicians; the decision to offer galactomannan testing within a hospital microbiology laboratory depends on resources, the institutional incidence of invasive aspergillosis, and the hospital casemix.

Details surrounding the release and kinetics of circulating galactomannan remain largely undefined. The growth phase, microenvironment, host immune status, and pathology may all influence galactomannan release. ${ }^{31}$ An abundance of data supports the notion that galactomannan production is proportional to fungal load in tissue; ${ }^{32-34}$ furthermore, galactomannan levels appear to have prognostic significance, with high unremitting levels in the face of antifungal therapy associated with an unfavourable outcome..$^{10,33-37}$

Assays to detect galactomannan have mostly used serum and BAL fluid. Galactomannan can also be detected in tissue and a number of bodily fluids including CSF, peritoneal fluid, urine, and pericardial fluid, although data to support its use at these sites is relatively scant, and is likely to remain that way. ${ }^{38}$

Galactomannan assays use EB-A2, a monoclonal antibody derived from rats, which is directed towards the $\beta(1,5)$-linked galactofuranoside side-chain residues of the galactomannan molecule. ${ }^{39}$ Four or more epitopes are required for antibody binding. ${ }^{31,39}$ Detection is achieved using a sandwich ELISA format, which is made possible by multiple immunoreactive epitopes on a single galactomannan molecule. ${ }^{39}$

There are a number of important determinants of analytical sensitivity of galactomannan assays. First, the binding of EB-A2 requires four or more galactofuranoside epitopes-sensitivity may be compromised by the inability to detect secreted antigens that bear fewer residues. ${ }^{31}$ Second, the Platelia assay is dependent on a pretreatment step, the goal of which is to remove complexing antibody that may block EB-A2 binding. However, the acid-sensitive galactofuranoside residues may be degraded by the edetic acid used in this step. ${ }^{31}$ Finally, the limit of detection using the sandwich ELISA format is lower $(1 \mathrm{ng} / \mathrm{L})$ than that achievable using latex agglutination $(15 \mathrm{ng} / \mathrm{L}){ }^{40}$ In terms of the analytical specificity, cross reactivity with other filamentous fungi, bacteria, drugs, and cotton swabs have been documented, ${ }^{41-45}$ but whether this is due to (exogenous) galactomannan or unrelated cross-reactive molecules is unclear.

There have been considerable efforts in establishing the appropriate galactomannan ELISA cut-off to maximise clinical sensitivity and specificity. The ELISA endpoint is a continuous variable and the optimal cut-off should be determined after defining the receiver-operator curve relation (ie, the relation between sensitivity and 1-specificity). ${ }^{46}$ The cut-off level of $1.5 \mathrm{ng} / \mathrm{L}$ initially recommended by BioRad and used in many early studies has been progressively revised downwards; a cut-off of $0.5 \mathrm{ng} / \mathrm{mL}$ is now currently accepted by the US Food and Drug Administration (FDA), while a level of $0.7 \mathrm{ng} / \mathrm{L}$ is commonly used in Europe. ${ }^{47}$

The clinical sensitivity of galactomannan ELISA is somewhat variable, with a range of $29-100 \% .{ }^{31}$ There are a number of potential reasons for these disparate results. First, the performance of the assay may differ according to the host group and therefore the underlying pathological process. In studies of profoundly immunocompromised patients, sensitivity has been generally reported to be in excess of $90 \%,{ }^{48,49}$ while in other settings-eg, chronic granulomatous disease ${ }^{50}$ and solid organ transplantation-sensitivity appears to be somewhat lower..$^{51-53}$ Second, accumulating evidence suggests that concomitant antifungal therapy leads to a decrease in the sensitivity of galactomannan. 32,36,54 Finally, inadequate sampling strategies could conceivably compromise clinical sensitivity; the optimal sampling strategy for screening has not been rigorously defined, but the twice weekly determination of antigen levels has been generally used in patients deemed to be at risk of invasive aspergillosis. By contrast, galactomannan levels should be determined immediately in a host with a constellation of clinical features indicative of invasive aspergillosis to facilitate a definitive diagnosis. 
The clinical specificity of galactomannan is generally estimated to be greater than $90 \% .^{32,36,47-49,55}$ The specificity of galactomannan in neonates and children appears to be lower, which is possibly due to the ingestion of extraneous galactomannan (in food and water) and translocation across a damaged or immature gut wall. ${ }^{45,47,56}$ Antibiotics represent an additional source of extraneous galactomannan that may compromise clinical specificity. The in-vitro reactivity of a range of antibiotics in galactomannan assays was originally reported in 1997.57 More recently, positive galactomannan results in patients receiving piperacillin-tazobactam have been documented.58,59 This phenomenon has been further explored in vitro and in vivo and probably relates to the presence of galactomannan within the drug itself. ${ }^{60,61}$ This finding has forced some institutions to change their antibacterial protocols and the FDA to issue a warning. ${ }^{62}$

\section{$(1,3)-\beta$-D glucan}

There has been an emergence of clinical data pertaining to the diagnostic utility of the cell wall component, $(1,3)-\beta-D$ glucan. ${ }^{63-67}(1,3)-\beta-D$ glucan assays have been developed by Wako Pure Chemical Industries (Tokyo, Japan), Seikagaku Kogyo Corporation (Tokyo, Japan), Maruha Corporation (Tokyo, Japan) and Associates of Cape Code (Falmouth, USA); the assay developed by Associates of Cape Code-Fungitell—has been approved by the FDA in the USA for the diagnosis of invasive fungal infections. $\beta$-D glucan is present in the cell wall of most fungi; the notable exceptions are Cryptococcus spp and the zygomycetes. ${ }^{67}$ The molecule is ubiquitous in the environment and has been used as a marker of fungal biomass. ${ }^{68}$ The presence of $(1,3)-\beta-D$ glucan in fungal species other than Aspergillus spp (eg, Candida spp, Fusarium spp, Acremonium spp, and Pneumocystis jiroveci) means that its role in establishing a specific diagnosis of invasive aspergillosis is not straightforward.

Assays to detect $(1,3)-\beta$-D glucan typically use serum. The common feature of all of the glucan assays is the ability of (1,3)- $\beta$-D glucan to activate a coagulation cascade within amoebocytes derived from the haemolymph of horseshoe crabs. Horseshoe crab lysate preparations were first used to detect endotoxin using the limulus test or limulus reaction (named after one type of horseshoe crab, Limulus polyphemus). Endotoxin induces clot formation via a serine protease zymogen named factor C (figure 2). Subsequently, evidence emerged that $(1,3)-\beta-D$ glucaninduced clot formation independently of factor $\mathrm{C}$, via a second serine protease zymogen, factor $\mathrm{G}$, thus providing the impetus for the development of the current assays.

The analytical sensitivity of the Fungitell assay is in the order of $1 \mathrm{pg} / \mathrm{mL}$, which is less than the cut-off of $60 \mathrm{pg} / \mathrm{mL}$ used in a recent clinical study. ${ }^{67} \mathrm{~A}$ technical consideration pertinent to the analytical sensitivity of $(1,3)$ $\beta-D$ glucan assays is that human plasma contains a number of inhibitors of serine proteases that need to be removed in a pretreatment step; this removal can be achieved by an alkali reagent method (Fungitell), or by the addition of Triton X-100 and heating to $70^{\circ} \mathrm{C}$ for 10 minutes (Wako assay). The alkali pretreatment step in the Fungitell assay also converts triple-helix glucans into single-helix structures, which appear to be more reactive. Since both endotoxin and (1,3)- $\beta$-D glucan activate the horseshoe crab coagulation pathway, an assay that specifically detects $(1,3)-\beta-D$ glucan requires removal of endotoxin from the specimen or the endotoxin-specific pathway from the lysate; correspondingly, endotoxin is inactivated by the addition of polymyxin in the pretreatment step in the Wako assay, while the Fungitell assay uses factor $\mathrm{C}$ to deplete limulus lysate. The pretreatment step also enhances analytical specificity via the removal of non-specific activators of serine proteases present in human serum.

There are no data that address the clinical sensitivity of the (1,3)- $\beta$-D glucan assays specifically for Aspergillus spp. The positive cut-off of $60 \mathrm{pg} / \mathrm{mL}$ was defined in a nonneutropenic group of patients with candidaemia. ${ }^{69}$ The performance of $(1,3)-\beta-D$ glucan in the context of antifungal therapy has not been rigorously studied. Falsepositive $(1,3)-\beta$-D glucan results have been documented in haemodialysis, cardiopulmonary bypass, treatment with immunoglobulin products, and exposure to glucancontaining gauze (eg, following major surgery). ${ }^{69}$ Environmental $(1,3)-\beta$-D glucan contamination may also compromise specificity.

\section{Antibodies directed toward Aspergillus spp}

The demonstration of specific antibody is required to establish the diagnosis of chronic pulmonary aspergillosis. ${ }^{69}$ Traditionally, antibody detection has not been considered useful for the diagnosis of acute invasive aspergillosis, following an early study that failed to document antibody formation in 15 patients with invasive aspergillosis. $^{70} \quad$ Subsequently, antibody has been documented in approximately one-third of patients with invasive aspergillosis. ${ }^{47,71}$ The detection of antibody may

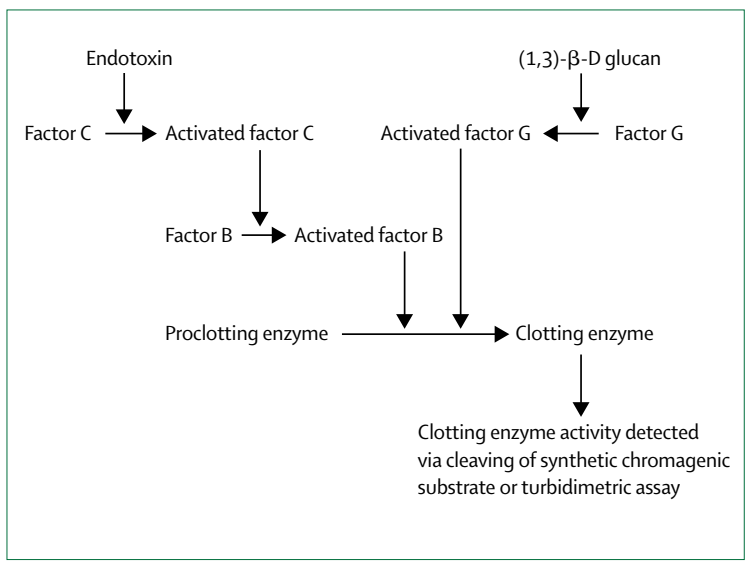

Figure 2: The pathways for the activation of the amoebocyte lysate by endotoxin and $(1,3)-\beta-D$ glucan and the use of this pathway for the detection of $(1,3)-\beta-D$ glucan 
prove to be the best non-invasive means of establishing the diagnosis of subacute invasive aspergillosis in nonneutropenic patients with invasive aspergillosis, as illustrated by a recent case report describing invasive pulmonary aspergillosis in an individual with chronic granulomatous disease. ${ }^{72}$ Furthermore, antibody detection could be useful as a means of establishing a retrospective diagnosis of invasive aspergillosis in profoundly immunocompromised hosts who have undergone immunological reconstitution, although more work is required in this regard.

\section{The detection of antibody}

Many assay formats have been used to detect antibodies to Aspergillus spp, including immunodiffusion, counter immunoelectrophoresis, complement fixation, particlehaemagglutination, indirect-immunofluoresence, radioimmunoassay, and ELISA. ${ }^{73,74}$ The large number of epitopes in crude extracts may compromise specificity. The use of recombinant antigens-eg, dipeptidylpeptidases, ${ }^{75}$ superoxide dismutase, ${ }^{75,76}$ catalase,$^{75}$ metalloprotease, ${ }^{75}$ mitogillin, ${ }^{77}$ and galactomannoprotein ${ }^{71,78}$-may rectify this situation. One potential advantage of using assays with a single antigen is the prospect of studying protective epitopes and thereby facilitating the generation of assays that may also confer prognostic information.

\section{Metabolites \\ Aspergillus spp produce a range of extracellular enzymes (eg, metalloproteases, phospholipases) as well as primary (eg, mannitol) ) $^{33}$ and secondary metabolites (eg, gliotoxin), ${ }^{79}$ all of which at least have the potential to serve as diagnostic markers for invasive aspergillosis. The ability of Aspergillus spp to produce D-mannitol has been known for many years ${ }^{80}$ and its diagnostic potential examined in several experimental models of invasive aspergillosis, ${ }^{33,81}$ although it is limited in terms of its broad applicability as a diagnostic tool because of the complexity of measurements, which are done by gas liquid chromatography and mass spectroscopy. Recent work suggests that gliotoxin is produced by most $A$ fumigatus strains and the possibility of using it as a diagnostic marker has been entertained. ${ }^{82} \mathrm{~A}$ comprehensive summary of the various secondary metabolites (mycotoxins) produced by Aspergillus spp can be found at http://www.aspergillus.man.ac.uk. The detection of metabolites represents an under-researched area in terms of their possible application as diagnostic modalities for invasive aspergillosis.}

\section{Nucleic acid tests}

As far as the amplification of nucleic acid and diagnosis of invasive aspergillosis is concerned, PCR technology has dominated. A limited number of publications have used the isothermal technique nucleic acid sequence-based amplification. ${ }^{83,84}$ Only PCR will be discussed here. The lack of standardisation of technical issues has and continues to represent a considerable barrier for the widespread application of PCR as a diagnostic modality for invasive aspergillosis and this is the focus of the following discussion. ${ }^{85}$

\section{Clinical specimens}

Many studies have addressed the detection of nucleic acid from various fractions of blood (serum, plasma, whole blood) to establish a diagnosis of invasive aspergillosis, but PCR may also be applied to BAL specimens ${ }^{86,87}$ and tissue ${ }^{88}$ including paraffin-embedded sections. ${ }^{89,90}$ The optimal blood fraction for the detection of aspergillus DNA remains unknown. One study, using quantitative PCR (qPCR), suggested that the yield of DNA from serum, plasma, and white cell pellet was similar, ${ }^{91}$ while another demonstrated that the (qualitative) PCR signal from whole blood was superior to plasma. ${ }^{92}$ Serum has the advantage that it enables concomitant antigen testing ${ }^{91}$ and does not require the addition of anticoagulants (eg, sodium citrate, edetic acid, or heparin) that may inhibit PCR. ${ }^{93}$

\section{DNA extraction}

There are a multitude of extraction techniques; the principal technical issues are summarised in table 1 . The chosen extraction method represents a compromise between efficiency, freedom from exogenous contamination, and applicability to routine high-throughput laboratories. The fungal cell wall clearly represents the major hurdle to high-efficiency extraction of fungal DNA. DNA may be extracted using in-house methods, commercial kits (eg, Qiagen QIAmp Tissue Kit [Hilden, Germany]), and automated commercial techniques (eg, MagNA Pure LC [Roche Diagnostics, Basel, Switzerland). Automated commercial techniques are probably required to make fungal DNA detection a viable option for routine clinical laboratories. The efficiency of extraction of fungal DNA may vary considerably between commercial kits. ${ }^{94}$ High speed cell disruption incorporating chaotropic reagents and lysing matrices provide efficient and high yields of DNA from Aspergillus spp and other filamentous fungi. ${ }^{95}$ Fungal contamination of extraction systems and reagents has been documented. ${ }^{96}$ Considerable differences in DNA extraction protocols and performance is one aspect of molecular assays that hinders the comparison of studies.

\section{Primer target}

For clinical diagnostic purposes, the detection of a broad range of fungi is important, as is the ability to ultimately identify the specific pathogen(s). The optimal approach, in this regard, involves the application of broad-ranging panfungal primers with post-amplification analysis for species determination. Panfungal primers are directed toward conserved regions, usually within multicopy genes, which flank sequences containing species specific 


\begin{tabular}{|c|c|c|}
\hline Feature & Definitions and goals & Specific considerations with respect to invasive aspergillosis \\
\hline Sample & $\begin{array}{l}\text { Sample type, volume, transport, and handling } \\
\text { should be defined }\end{array}$ & $\begin{array}{l}\text { Serum and white cell pellet equivalent and possibly superior to plasma as sample } \\
\text { Heparin and citrate inhibitory to PCR } \\
\text { Sample handling varies between studies (some have demonstrated stability at room temperature } \\
\text { for } 48 \mathrm{~h} \text {, others recommend immediate freezing) }\end{array}$ \\
\hline \multirow[t]{6}{*}{ DNA extraction } & $\begin{array}{l}\text { Target is of an adequate concentration and quality } \\
\text { for amplification. PCR inhibitors and DNA nucleases } \\
\text { removed }\end{array}$ & $\begin{array}{l}\text { Extraction efficiency for fungal DNA is low due to the requirement to break the cell wall } \\
\text { Contamination rate } 3 \cdot 3 \% \text { in one series, commercial reagents may be contaminated with } \\
\text { fungal DNA } \\
\text { Ideally negative and positive extraction controls should be used }\end{array}$ \\
\hline & Removal of red and white cells & Red cell lysis buffer and white cell lysis buffer \\
\hline & Disruption of cell wall & $\begin{array}{l}\text { Enzymatic methods (eg, lyticase, zymolase) } \\
\text { Chemical (eg, boiling in dilute alkali) } \\
\text { Physical (eg, glass bead milling, freeze-thawing, sonication, grinding in liquid nitrogen) }\end{array}$ \\
\hline & Disruption of cell membrane & Usually achieved with lysis buffer (sodium dodecyl sulphate, beta-mercaptoethanol, EDTA) \\
\hline & Precipitation of protein and purification of DNA & $\begin{array}{l}\text { Phenol-chloroform } \\
\text { Silica fibres (eg Oiagen Tissue Kit) }\end{array}$ \\
\hline & Capture of DNA & $\begin{array}{l}\text { Alcohol precipitation } \\
\text { Magnetic beads (eg, MagNA Pure) } \\
\text { Silica fibres (eg, Qiagen Tissue Kit) }\end{array}$ \\
\hline Amplification & $\begin{array}{l}\text { Nested PCR, real-time formats, PCR-ELISA represent } \\
\text { the commonest formats }\end{array}$ & $\begin{array}{l}\text { Nested formats potentially allow for optimal analytical sensitivity but are associated with } \\
\text { contamination and are difficult to compare } \\
\text { Real-time formats will probably dominate in the future }\end{array}$ \\
\hline & Amplification controls & Negative and positive controls are required \\
\hline $\begin{array}{l}\text { Analytical } \\
\text { sensitivity }\end{array}$ & $\begin{array}{l}\text { The smallest number of target organisms reliably and } \\
\text { reproducibly detected by the assay }\end{array}$ & $\begin{array}{l}\text { Multicopy target preferable } \\
\text { Assessed by serial dilution of Aspergillus spp (conidia or purified DNA) using the appropriate } \\
\text { clinical specimen as the diluent } \\
\text { Circulating DNA in invasive aspergillosis is typically less than } 10 \text { colony forming units per } \mathrm{mL} \\
\text { or less than } 30 \mathrm{fg} \\
\text { Extraction method, primer target, and detection method all influence analytical sensitivity }\end{array}$ \\
\hline $\begin{array}{l}\text { Analytical } \\
\text { specificity }\end{array}$ & Does the test detect only what it purports to? & $\begin{array}{l}\text { Specific primer and probe sequences initially identified from public databases } \\
\text { Amplicon ideally should be sequenced and a BLAST search done } \\
\text { Cross reactivity studies with a range of fungal and bacterial pathogens as well as human DNA } \\
\text { are required } \\
\text { Post-amplification detection probe(s) may enhance specificity }\end{array}$ \\
\hline $\begin{array}{l}\text { Inhibition } \\
\text { controls }\end{array}$ & Inhibitors of DNA polymerase (eg, heparin) & $\begin{array}{l}\text { Spiking with purified aspergillus DNA and analysing in a separate reaction } \\
\text { Spiking with a plasmid construct containing different size and sequence or label to the target } \\
\text { Amplifying a human housekeeping gene (eg, betaglobin, HLA2), which also allows some } \\
\text { determination of specimen adequacy, although the relative dominance of human DNA in clinical } \\
\text { samples may mask low levels of inhibitors which could interfere with target amplification }\end{array}$ \\
\hline $\begin{array}{l}\text { Contamination } \\
\text { control }\end{array}$ & $\begin{array}{l}\text { Uracil-D-glycolase, appropriate number of } \\
\text { negative controls }\end{array}$ & \\
\hline
\end{tabular}

polymorphisms that can be exploited in post-amplification analysis.

The ribosomal DNA (rDNA) complex is the most common target. This complex contains both conserved and variable sequences and there is a large volume of data deposited in public databases for a wide range of genera and species. The recent genome sequencing of A fumigatus, using strain Af293, revealed 35 repeating units; ${ }^{97}$ the structure of the gene complex is illustrated in figure $3 .^{98}$ The mitochondrial genes encoding some of the tRNA genes ${ }^{91}$ and (apo)cytochrome $b^{99}$ have also been used as primer targets. Mitochondrial targets can be considered "multicopy" because of a multiple number of mitochondria per cell nucleus; in Af293, there were 12 copies of the mitochondrial genome present for every copy of the nuclear genome. ${ }^{97}$

\section{Amplification format}

Nested PCR formats have been widely used for Aspergillus spp in an attempt to optimise analytical sensitivity, but the requirement to open reaction tubes means that there is considerable risk of contamination and the subsequent generation of false-positive results. Real-time formats have been increasingly used and are likely to dominate in the near future.

\section{Post-amplification analysis}

Post-amplification detection techniques provide genus or species specific data but may also increase sensitivity and specificity. ${ }^{100,101}$ Real-time detection techniques (eg, TaqMan, LightCycler, molecular beacons) are automated, rapid, and reproducible, thus facilitating comparisons between studies. Southern blotting has had a valuable role in the evolution of PCR as a diagnostic modality, but is unlikely to have any substantial future role in routine clinical assays. Single-strand conformational polymorphism, ${ }^{102,103}$ restriction fragment length polymorphism digest pattern, ${ }^{104}$ Line Probes, ${ }^{105}$ fragment size determination, ${ }^{106}$ and PCR-ELISA ${ }^{107}$ may have a limited role 
in specific instances, such as the identification of laboratory isolates.

\section{Analytical sensitivity and specificity}

The analytical sensitivity of a molecular assay is usually determined by serial dilution of the infectious agent in pooled non-infectious clinical material as the diluent. ${ }^{108}$ Such a paradigm immediately presents a problem for Aspergillus spp or any other mould, since accurate and indeed meaningful dilution of hyphae is not possible. Two commonly used approaches include serial dilution of conidia or DNA (either purified genomic DNA or a plasmid construct), although neither are ideal; the former does not mimic a biologically valid scenario, since hyphae rather than conidia are the invasive form, while the latter does not control for issues in extraction efficiency. If it is intended that more than one species is detectable then DNA from those species should be included in the assessment of analytical sensitivity. ${ }^{109}$ The analytical sensitivity of published assays varies by several orders of magnitude; however, most studies report detection limits in the order of 1-10 fg DNA; variability in the detection limit is yet another issue that compromises study comparability.

Studies differ considerably in terms of the methods and extent to which analytical specificity is determined; there

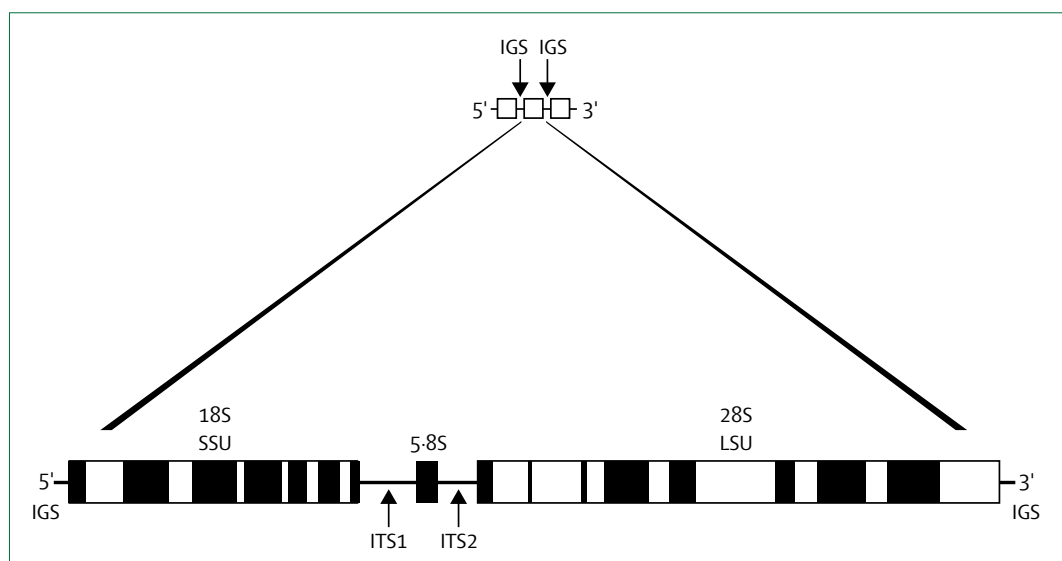

Figure 3: The structure of the ribosomal DNA complex

Shaded areas denote areas of variability that are present throughout the complex that can be exploited to design assays of varying levels of specificity. IGS=intergenic spacer; ITS=internal transcribed spacer; LSU=long subunit; SSU=short subunit. Adapted from reference 98.

are no standard techniques or criteria (table 2). Primer targets are generally identified by aligning sequences retrieved from public databases. This practice should be viewed as a necessary but insufficient step in establishing the analytical specificity of an assay and further validation procedures are required. Ideally, relatively early in assay

\begin{tabular}{|c|c|c|c|c|c|}
\hline Primer target & Assay format & $\begin{array}{l}\text { Intended } \\
\text { specificity }\end{array}$ & $\begin{array}{l}\text { BLAST search of primer and probe sequences; isolates } \\
\text { with same probability match as intended target }\end{array}$ & Method by which analytical specificity determined and result & Reference \\
\hline 18S rRNA & PCR-ELISA & Aspergillus spp & $\begin{array}{l}\text { Aspergillus spp, Penicillium italicum, Penicillium commune, Penicillium } \\
\text { chryosogenum, Penicillium brevicompactum, Penicillium phialosporum, } \\
\text { Penicillium tardum, Penicillium allii, Penicillium expansum, Ajellomyces } \\
\text { capsulatus (telemorph of Histoplasma capsulatum), Paracoccidiodes } \\
\text { brasiliensis, Eupenicillium spp, Penicilliopsis spp }\end{array}$ & $\begin{array}{l}\text { Cross-reactivity studies: } \\
\text { Amplification of Aspergillus fumigatus, Aspergillus flavus, Aspergillus } \\
\text { terreus, Aspergillus niger, Aspergillus nidulans, Aspergillus versicolor, } \\
\text { Histoplasma capsulatum } \\
\text { No amplification of Malassezia furfur (3 strains), Fusarium spp (3 strains), } \\
\text { Trichosporon cutaneum ( } 2 \text { strains), Mucor spp (3 strains), Penicillium spp } \\
\text { (2 strains), Pseudallescheria boydii (1 strain), Paecilomyces spp ( } 2 \text { strains), } \\
\text { Saccharomyces cerevisiae (2 strains) }\end{array}$ & $\begin{array}{l}\text { Einsele } \\
\text { et al }^{110}\end{array}$ \\
\hline 18S rRNA & TaqMan & Aspergillus spp & $\begin{array}{l}\text { Aspergillus spp, P italicum, Penicillium glabrum, P commune, } \\
\text { Pchryosogenum, P brevicompactum, P phialosporum, Penicillium } \\
\text { purpurogenum, P tardum, Penicillium verruculosum, Penicillium hirsutum, } \\
\text { Penicillium radicum, Penicillium funiculosum, Penicillium siamense, } \\
\text { Penicillium pittii, Penicillium minioluteum, Penicillium pinophilum, } \\
\text { Penicillium variabile, Penicillium rugulosum, Penicillium crateriforme, } \\
\text { Penicillium variotii, Eupenicillium spp, and others }\end{array}$ & $\begin{array}{l}\text { Cross-reactivity studies: } \\
\text { Ampification of A fumigatus, A niger, A terreus, A flavus, Aspergillus oryzae } \\
\text { No amplification of Candida albicans, Candida tropicalis, Candida krusei, } \\
\text { Candida parapsilosis, Candida glabrata, Candida guilliermondii }\end{array}$ & $\begin{array}{l}\text { Kami } \\
\text { et } a^{111}\end{array}$ \\
\hline $\begin{array}{l}\text { Mitochondrial } \\
\text { DNA (tRNA) }\end{array}$ & $\begin{array}{l}\text { Competitive PCR } \\
\text { with PCR-ELISA }\end{array}$ & Aspergillus spp & A fumigatus & $\begin{array}{l}\text { Cross-reactivity studies: } \\
\text { Ampification of } 30 \text { isolates of A fumigatus, A niger, A terreus, A flavus } \\
\text { No amplification of A nidulans, C albicans, C tropicalis, C krusei, } \\
\text { C parapsilosis, C glabrata, Cryptococcus neoformans }\end{array}$ & $\begin{array}{l}\text { Bretagne } \\
\text { et } \mathrm{al}^{112}\end{array}$ \\
\hline $\begin{array}{l}\text { Mitochondrial } \\
\text { DNA (tRNA) }\end{array}$ & $\begin{array}{l}\text { Competitive PCR } \\
\text { with PCR-ELISA }\end{array}$ & $\begin{array}{l}\text { A fumigatus, } \\
\text { A flavus }\end{array}$ & No database matches & $\begin{array}{l}\text { Amplicon sequenced: revealing A fumigatus and A flavus } \\
\text { Cross-reactivity studies: } \\
\text { No ampification of A niger, A terreus, A nidulans, Aspergillus ustus, } \\
\text { Penicillium purporogenum, Scopulariopsis brevicaulis }\end{array}$ & $\begin{array}{l}\text { Bretagne } \\
\text { et } \mathrm{al}^{113}\end{array}$ \\
\hline $\begin{array}{l}\text { Mitochondrial } \\
\text { DNA (tRNA) }\end{array}$ & LightCycler & A fumigatus & A fumigatus & $\begin{array}{l}\text { None, although clinical specificity assessed using } 20 \text { serum samples from } \\
\text { healthy individuals }\end{array}$ & $\begin{array}{l}\text { Costa } \\
\text { et al }{ }^{91}\end{array}$ \\
\hline $\begin{array}{l}\text { Mitochondrial } \\
\text { DNA (cyto- } \\
\text { chrome b) }\end{array}$ & LightCycler & A fumigatus & Eupenicillium shearii, Neosartorya fischerii, A fumigatus & $\begin{array}{l}\text { Cross-reactivity studies: } \\
\text { Amplification of A fumigatus, Aspergillus clavatus } \\
\text { No amplification of Candida spp, other Aspergillus spp, P chryosegenum, } \\
\text { Pexpansum, P funiculosum, P variotii, Rhizopus oryzae, Fusarium proliferatum }\end{array}$ & $\begin{array}{l}\text { Spiess } \\
\text { et a }{ }^{99}\end{array}$ \\
\hline
\end{tabular}




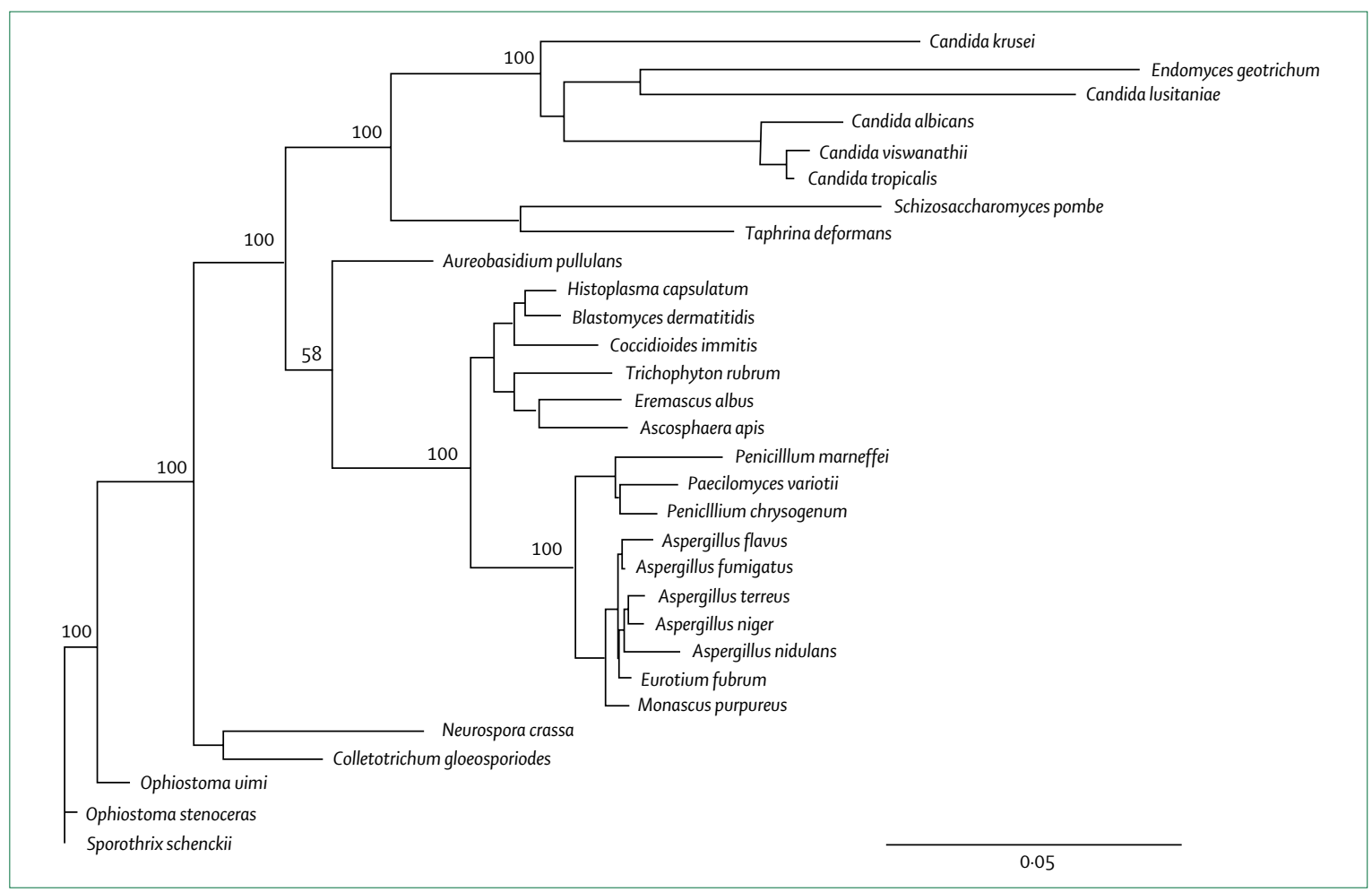

Figure 4: The phylogenetic relations between Aspergillus spp and other fungi based on the $18 \mathrm{~S}$ rRNA complex

Adapted from reference 114 .

development, the amplicon should be sequenced and a BLAST search done to verify that the intended target has been amplified. ${ }^{109}$ Subsequently, the assay should be challenged with organisms that have a high likelihood of cross-reacting with the target; in the case of Aspergillus spp, genera that are close phylogenetic relations-eg, Penicillium spp and Paecilomyces $\mathrm{spp}^{114}$ are especially important to consider (figure 4). A further consideration is that sequences are being continuously deposited in public databases; a unique sequence at the time of primer design may subsequently align with a sequence from an unrelated species or genus deposited at a later date. Some have suggested that BLAST searches are done on an annual basis to ensure there is no cross reactivity with recently submitted sequence. ${ }^{109}$ A final consideration is that false-positive reactions due to carry-over contamination of amplicon from previous reactions may be prevented with the addition of uracil-D-glycolase. ${ }^{85}$

\section{Clinical sensitivity and specificity}

There are a number of factors that potentially have an impact upon the clinical sensitivity of PCR. The magnitude of the quantitative PCR signal falls with antifungal therapy in both experimental models and in clinical contexts - this may account for false-negative PCR results. ${ }^{110,111,115,116}$ Patients at risk for invasive aspergillosis are also often prescribed a multitude of drugs and fluids, all of which may act as non-specific inhibitors of PCR; as a result, inhibition controls are mandatory and may take the form of spiking the sample with aspergillus DNA, a plasmid construct, or amplification of a human gene such as betaglobin (table 1).

\section{The application of diagnostic modalities Laboratory isolates}

Given the distinct differences in disease manifestations, prognosis, and antifungal susceptibility between different fungal genera and species, a rapid diagnosis will assume increasing importance. The inherent problems with identification using culture methods have been outlined. An increasing number of studies have examined the use of PCR to enable the accurate and rapid detection of laboratory isolates (table 3 ). The rapid identification of laboratory isolates using microarray technology with a panfungal chip is possible and no doubt the relevant studies will emerge in the near future.

\section{Clinical specimens}

The application of diagnostic modalities to tissue, respiratory tract secretions, and blood in the context of the pathophysiology of invasive pulmonary aspergillosis is illustrated in figure 5.

\section{Tissue and sterile fluids}

Histological and culture techniques applied to tissue form the reference diagnostic standard for invasive 
aspergillosis $^{11}$ and have been, and continue to be, the standard tools by which tissue invasion and destruction by hyphae is documented. Within this context, the following points specifically deserve emphasis. First, difficulties in obtaining deep tissue specimens in patients who are least able to tolerate invasive procedures have been exhaustively documented and remain one of the principal factors driving the development of new diagnostic techniques. Second, the analytical sensitivity of both histology and culture is relatively low, meaning that invasive disease is well established by the time that culture and histology are positive. Third, the specificity of the reference standard for Aspergillus spp is optimised with the combination of histological and culture data and this rigorous standard has been used in some recent clinical trials. ${ }^{48,120}$ The problem, however, is that Aspergillus spp can only be recovered from tissue in the context of positive histology in $30-50 \%$ of cases. ${ }^{24}$ Finally, the possibility of accepting a positive PCR result in tissue as the reference standard for invasive aspergillosis deserves increasing attention. Certainly, data from experimental models suggests that validated PCR is more sensitive than culture for the detection of Aspergillus spp in tissue, especially in the setting of substantial tissue necrosis; ${ }^{.15,121}$ the key in this regard is assay validation.

\section{Non-sterile sites}

In the absence of tissue specimens, samples obtained from contiguous non-sterile sites-eg, the upper and lower respiratory tract-serve as a surrogate with which to establish the diagnosis of invasive aspergillosis. In the case of invasive pulmonary aspergillosis, viable hyphal elements or related serological or molecular markers are shed into the respiratory tract from infected parenchyma (figure 5). A body of data suggests this shedding occurs relatively late in the natural history, thus compromising attempts to establish an early diagnosis using this approach..$^{25,122,123}$ The isolation of Aspergillus spp (or related serological, molecular, or biochemical markers) in the respiratory tract may represent one of three scenarios: (1) evidence of current disease, (2) true colonisation, or (3) a marker for the future development of invasive disease. An example of the latter is provided by a study that demonstrated that a positive PCR result from BAL at the time of bone marrow transplant conditioning was predictive of the subsequent development of invasive pulmonary aspergillosis. ${ }^{124}$

There are a number of points to make about using BAL specimens to secure a diagnosis of invasive pulmonary aspergillosis. First, although BAL is a safe procedure, even in patients with substantial immunological impairment, it is not a trivial undertaking and requires a dedicated and competent bronchoscopist and an adequate commitment of resources. Second, the overall sensitivity (using culture and microscopy) is relatively low and generally estimated to be in the order of $50 \% .^{122,123,125,126}$ Variations in BAL technique, ${ }^{127}$ the location, size, and type of pulmonary lesions, ${ }^{128-130}$ and the timing of bronchoscopy ${ }^{122}$ are all important determinants of the overall estimate. The impact of antifungal therapy in terms of the recovery of aspergillus and related markers in the respiratory tract remains poorly defined. Third, the specificity of the isolation of Aspergillus spp from the respiratory tract in patients with substantial immunological impairmenteg, those with allogeneic haematopoietic stem cell transplantation or neutropenia-is very high, ${ }^{131}$ but for other patient groups, the likelihood of underlying invasive pulmonary aspergillosis varies enormously. ${ }^{25,131}$ Fourth, qPCR may prove to be especially useful in determining the relation between the fungal burden in the respiratory tract and the probability of underlying invasive disease $;^{87,99,115}$ however, at the current time, the benefit of PCR over conventional culture remains to be further defined. Finally, the diagnostic yield from BAL fluid is potentially optimised with the application of more than one test; a recent study demonstrated sensitivity was improved with the concomitant application of galactomannan and PCR. ${ }^{130}$

\begin{tabular}{|c|c|c|c|c|c|}
\hline Specimen & Target & Demonstrated specificity & PCR format & Detection method & Reference \\
\hline Cultures & ITS1-5.8S rRNA-ITS2 & Aspergillus fumigatus, Aspergillus flavus, Aspergillus & Conventional & Sequencing of amplicon & Henry et $\mathrm{al}^{117}$ \\
\hline Cultures & ITS1-5.8S rRNA-ITS2 & $\begin{array}{l}\text { terreus, Aspergillus niger, Aspergillus ustus } \\
\text { A fumigatus, A flavus, Aspergillus nidulans, Aspergillus } \\
\text { versicolor }\end{array}$ & Conventional & Line probe & Martin et al ${ }^{105}$ \\
\hline Cultures & ITS1-5.8S rRNA-ITS2 & A fumigatus, A flavus, A terreus, A niger, A nidulans & Conventional & SSCP & Rath et a $\left.\right|^{103}$ \\
\hline Cultures & ITS1-5.8S rRNA-ITS2 & A fumigatus & Multiplex PCR & Ethidium bromide & Luo et $\mathrm{a}^{118}$ \\
\hline Cultures & ITS1-5.8S rRNA-ITS2 & A fumigatus & Nested & Ethidium bromide & Zhao et al ${ }^{119}$ \\
\hline Cultures & $5 \cdot 8 \mathrm{~S}$ rRNA-ITS2 region & A fumigatus, A flavus, A terreus, A niger & Conventional & $\begin{array}{l}\text { Automated fluorescent capillary } \\
\text { electrophoresis (detection of } \\
\text { different length of amplicon) }\end{array}$ & Turenne et al ${ }^{106}$ \\
\hline Cultures & 18S rRNA & A fumigatus, A terreus & Conventional & SSCP & Walsh et al ${ }^{102}$ \\
\hline $\begin{array}{l}\text { Cultures and } \\
\text { tissue }\end{array}$ & ITS2 & $\begin{array}{l}\text { Aspergillus spp and Penicillium spp, A fumigatus, A flavus, } \\
\text { A terreus, A niger, A nidulans, A ustus, A versicolor }\end{array}$ & Conventional & PCR-ELISA & De Aguirre et al ${ }^{107}$ \\
\hline$=5$ & Tondal pory! & rphism & & & \\
\hline
\end{tabular}




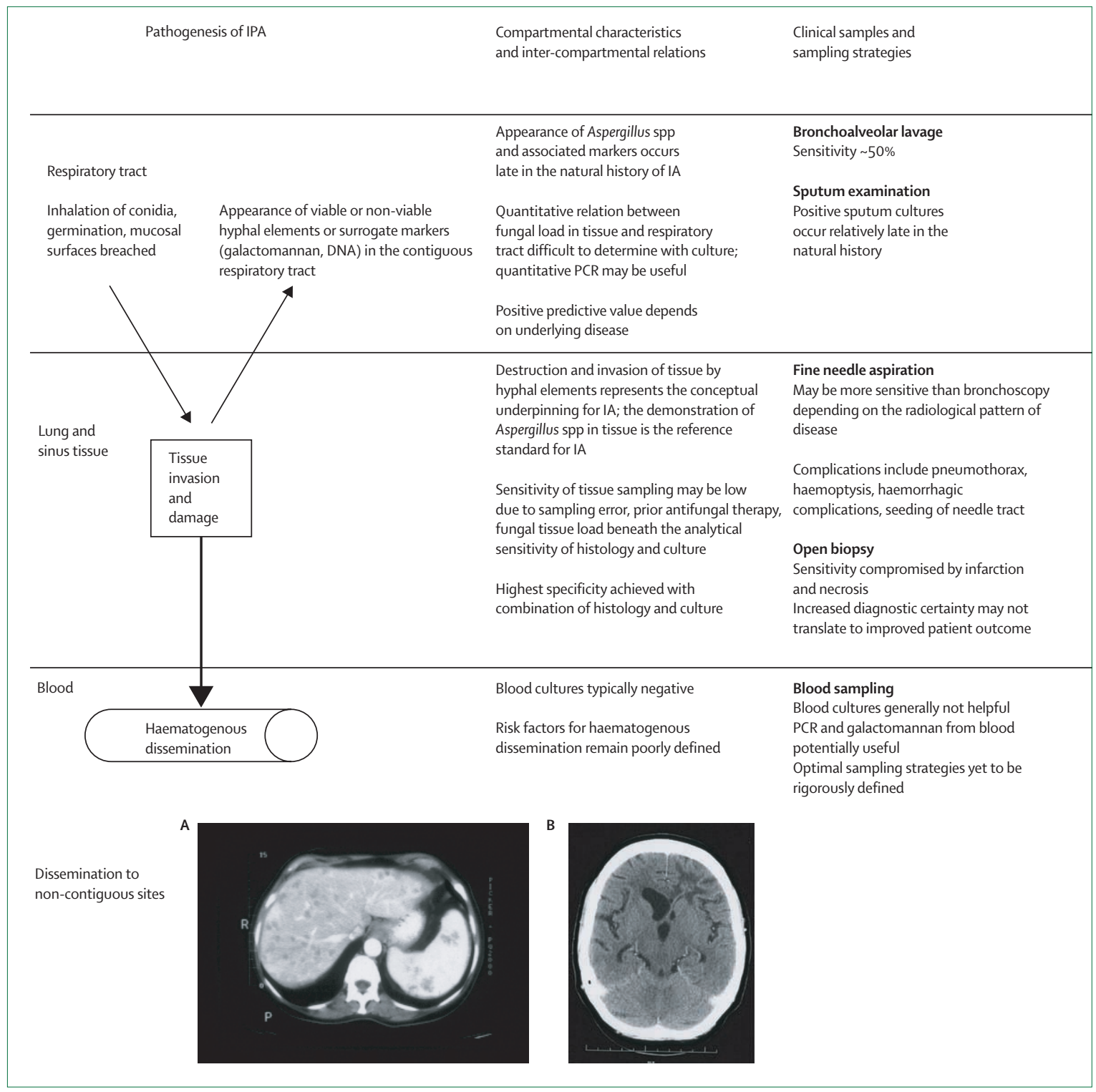

Figure 5: Compartmental characteristics, inter-compartmental relations, and sampling strategies as they relate to the pathogenesis of invasive pulmonary aspergillosis

(A) Hepatosplenic aspergillosis (courtesy of Damon Eisen). (B) Cerebral abscess due to Aspergillus fumigatus. IA=invasive aspergillosis.

\section{Blood}

Blood sampling represents the optimal non-invasive diagnostic approach for invasive aspergillosis. Despite their propensity for vascular invasion, Aspergillus spp are only very infrequently isolated from blood using conventional culture techniques, hence the traditional dependence on tissue specimens to secure a definitive diagnosis of invasive aspergillosis. There is an extensive body of literature examining the diagnostic utility of molecular and serological techniques in blood. Galactomannan has been incorporated into diagnostic criteria for invasive aspergillosis and the technical issues required for PCR to be applied in the same manner have been discussed. However, there remain some additional pertinent issues. First, specific sampling strategies are yet to be systematically studied-yield is almost certainly a function of the volume and frequency of sampling, as is the case with blood cultures. Second, the appropriate interpretation of a positive galactomannan or validated PCR result in a patient at risk of invasive aspergillosis, but without subsequent evidence of invasive disease, remains unclear and difficult to resolve; the most conservative interpretation in this context is that all single positive results are false-positive, but at least on occasion, such results may reflect true invasive disease that has aborted or is non-progressive. Third, a body of evidence suggests 


\section{Search strategy and selection criteria}

PubMed was searched for English-language literature using the following terms: "Aspergillus", "aspergillosis", "diagnosis", "fungus", "fungal", "culture", "histology", "galactomannan", "glucan", "serology", "antibody", "PCR", "molecular", "metabolite", "mannitol", and "gliotoxin". Further relevant references, not identified by this strategy, were retrieved from the primary publications.

that both PCR and galactomannan may enable a specific diagnosis to be established earlier than is possible using a conventional approach. ${ }^{32,49,132}$ Fourth, the combination of different diagnostic modalities-eg, concomitant measurement of galactomannan and $(1,3)-\beta-D$ glucan-is a strategy that may optimise diagnostic accuracy. ${ }^{63}$ Finally, it seems likely that both PCR and galactomannan engender important prognostic information; a falling galactomannan titre or a positive-turning-negative PCR signal in the context of antifungal therapy is usually associated with a successful outcome. However, at the current time, galactomannan and PCR have not been systematically used to guide antifungal therapy.

\section{The incorporation of diagnostic data into management strategies}

Galactomannan (and validated PCR) applied to blood can be used as screening tools to further improve the identification of patients at high risk of developing invasive aspergillosis. ${ }^{133}$ A positive result may enable the start of early targeted antifungal chemotherapy, while expensive and potentially toxic antifungal drugs can be withheld with persistently negative results. Testing for $(1,3)$ - $\beta$-D-glucan could be also be useful in this regard. When the assays are used in this manner, a positive result should also serve as a trigger for additional diagnostic evaluation-eg, a high-resolution computed tomography scan of the thorax- to investigate the possibility of a subclinical focus of infection. The success of galactomannan (and validated PCR) as a screening tool is largely dependent on the underlying prevalence of invasive aspergillosis, which varies according to the specific host group and institution; thus, the requirement and extent of galactomannan screening may vary accordingly.

An alternate diagnostic strategy is to reserve galactomannan and validated PCR for situations in which clinical and radiological data are suggestive of invasive aspergillosis; in this scenario, galactomannan and validated PCR applied to serum, and other tissues and fluids, may enable a definitive diagnosis of invasive aspergillosis to be secured. Although this approach does not facilitate early antifungal therapy, it may minimise the use of invasive diagnostic modalities. Furthermore, a more definitive diagnosis enables the administration of specific anti-aspergillus therapy and would be of considerable benefit for future diagnostic and therapeutic research.

\section{Future challenges}

Invasive aspergillosis continues to pose many challenges. From a diagnostic point of view, improving the test accuracy remains a priority for patient care, therapeutic research, and future diagnostic research. The question, of course, is the manner in which these improvements can be achieved. The progressive refinement of existing techniques and development of new diagnostic technologies is clearly a priority. Substantial work remains in areas related to cost-effectiveness and whether patients who undergo intensive diagnostic testing have improved outcome. Just as importantly, however, is the generation of a clinical environment and culture that is amenable to high quality diagnostic research, the provision of adequate funding, multicentre participation, international collaboration, and rigorous study design.

\section{Conflicts of interest}

WWH is supported by an unrestricted educational grant from Merck \& Co and the Fungal Research Trust. TJW and DWD have no conflicts of interest to declare.

\section{Acknowledgments}

We thank Ruta Petraitiene for the photomicrographs in figure 1.

References

1 Perfect JR, Cox GM, Lee JY, et al. The impact of culture isolation of Aspergillus species: a hospital-based survey of aspergillosis. Clin Infect Dis 2001; 33: 1824-33.

2 Segal BH, DeCarlo ES, Kwon-Chung KJ, Malech HL, Gallin JI, Holland SM. Aspergillus nidulans infection in chronic granulomatous disease. Medicine (Baltimore) 1998; 77: 345-54.

3 von Eiff M, Roos N, Schulten R, Hesse M, Zuhlsdorf M, van de Loo J. Pulmonary aspergillosis: early diagnosis improves survival. Respiration 1995; 62: 341-47.

4 Wald A, Leisenring W, van Burik JA, Bowden RA. Epidemiology of Aspergillus infections in a large cohort of patients undergoing bone marrow transplantation. J Infect Dis 1997; 175: 1459-66.

5 Grow WB, Moreb JS, Roque D, et al. Late onset of invasive Aspergillus infection in bone marrow transplant patients at a university hospital. Bone Marrow Transplant 2002; 29: 15-19.

6 Alangaden GJ, Wahiduzzaman M, Chandrasekar PH. Aspergillosis: the most common community-acquired pneumonia with gramnegative bacilli as copathogens in stem cell transplant recipients with graft-versus-host disease. Clin Infect Dis 2002; 35: 659-64.

7 Meersseman W, Vandecasteele SJ, Wilmer A, Verbeken E, Peetermans WE, Van Wijngaerden E. Invasive aspergillosis in critically ill patients without malignancy. Am J Respir Crit Care Med 2004; 170: 621-25

8 Hachem RY, Kontoyiannis DP, Boktour MR, et al. Aspergillus terreus: an emerging amphotericin B-resistant opportunistic mold in patients with hematologic malignancies. Cancer 2004; 101: 1594-600.

9 Steinbach WJ, Benjamin DK Jr, Kontoyiannis DP, et al. Infections due to Aspergillus terreus: a multicenter retrospective analysis of 83 cases. Clin Infect Dis 2004; 39: 192-98.

10 Walsh TJ, Petraitis V, Petraitiene R, et al. Experimental pulmonary aspergillosis due to Aspergillus terreus: pathogenesis and treatment of an emerging fungal pathogen resistant to amphotericin B. J Infect Dis 2003; 188: 305-19.

11 Ascioglu S, Rex JH, de Pauw B, et al. Defining opportunistic invasive fungal infections in immunocompromised patients with cancer and hematopoietic stem cell transplants: an international consensus. Clin Infect Dis 2002; 34: 7-14.

12 Merz WG, Roberts GD. Algorithims for detection and identification of fungi. In: Murray PR, Baron EJ, Pfaller MA, Tenover FC, Yolken RH, eds. Manual of clinical microbiology, 7th edn. Washington DC: ASM Press, 1999: 1167-83. 
13 Denning DW, Kibbler CC, Barnes RA. British Society for Medical Mycology proposed standards of care for patients with invasive fungal infections. Lancet Infect Dis 2003; 3: 230-40.

14 Grocott RG. A stain for fungi in tissue sections and smears using Gomori's methenamine-silver nitrate technic. Am J Clin Pathol 1955; 25: 975-79.

15 Ruchel R, Schaffrinski M. Versatile fluorescent staining of fungi in clinical specimens by using the optical brightener Blankophor. J Clin Microbiol 1999; 37: 2694-96.

16 Chander J, Chakrabarti A, Sharma A, Saini JS, Panigrahi D. Evaluation of Calcofluor staining in the diagnosis of fungal corneal ulcer. Mycoses 1993; 36: 243-45.

17 Choi JK, Mauger J, McGowan KL. Immunohistochemical detection of Aspergillus species in pediatric tissue samples. Am J Clin Pathol 2004; 121: 18-25.

18 Kaufman L, Standard PG, Jalbert M, Kraft DE. Immunohistologic identification of Aspergillus spp. and other hyaline fungi by using polyclonal fluorescent antibodies. J Clin Microbiol 1997; 35: 2206-09.

19 Verweij PE, Smedts F, Poot T, Bult P, Hoogkamp-Korstanje JA, Meis JF. Immunoperoxidase staining for identification of Aspergillus species in routinely processed tissue sections. J Clin Pathol 1996; 49: 798-801.

20 De Vos MM, Nelis HJ. Detection of Aspergillus fumigatus hyphae by solid phase cytometry. J Microbiol Methods 2003; 55: 557-64.

21 Zimmerman RL, Montone KT, Fogt F, Norris AH. Ultra fast identification of Aspergillus species in pulmonary cytology specimens by in situ hybridization. Int J Mol Med 2000; 5: 427-29.

22 Hayden RT, Isotalo PA, Parrett T, et al. In situ hybridization for the differentiation of Aspergillus, Fusarium, and Pseudallescheria species in tissue section. Diagn Mol Pathol 2003; 12: 21-26.

23 Kontoyiannis DP, Lewis RE, May GS, Osherov N, Rinaldi MG Aspergillus nidulans is frequently resistant to amphotericin B. Mycoses 2002; 45: 406-07.

24 Tarrand JJ, Lichterfeld M, Warraich I, et al. Diagnosis of invasive septate mold infections. Am J Clin Pathol 2003; 119: 854-58.

25 Horvath JA, Dummer S. The use of respiratory-tract cultures in the diagnosis of invasive pulmonary aspergillosis. Am J Med 1996; 100: 171-78.

26 Sutton DA. Specimen collection, transport, and processing: mycology. In: Murray PR, Baron EJ, Jorgensen JH, Pfaller MA, Yolken RH, eds. Manual of clinical microbiology, 8th edn. Washington DC: ASM Press, 2003: 1659-67.

27 de Hoog GS, Guarro J, Gene J, Figueras MJ. Atlas of clinical fungi, 2nd edn. Utrecht: Centraalbureau voor Schimmelcultures, 2000.

28 Klich MA. Identification of common Aspergillus species. Utrecht: Centraalbureau voor Schimmelcultures, 2002.

29 Callister ME, Griffiths MJ, Nicholson AG, et al. A fatal case of disseminated aspergillosis caused by a non-sporulating strain of Aspergillus fumigatus. J Clin Pathol 2004; 57: 991-92.

30 Latge JP, Kobayashi H, Debeaupuis JP, et al. Chemical and immunological characterization of the extracellular galactomannan of Aspergillus fumigatus. Infect Immun 1994; 62 5424-33.

31 Mennink-Kersten MA, Donnelly JP, Verweij PE. Detection of circulating galactomannan for the diagnosis and management of invasive aspergillosis. Lancet Infect Dis 2004; 4: 349-57.

32 Marr KA, Balajee SA, McLaughlin L, Tabouret M, Bentsen C, Walsh TJ. Detection of galactomannan antigenemia by enzyme immunoassay for the diagnosis of invasive aspergillosis: variables that affect performance. J Infect Dis 2004; 190: 641-49.

33 Francis P, Lee JW, Hoffman A, et al. Efficacy of unilamellar liposomal amphotericin B in treatment of pulmonary aspergillosis in persistently granulocytopenic rabbits: the potential role of bronchoalveolar D-mannitol and serum galactomannan as markers of infection. J Infect Dis 1994; 169: 356-68.

34 Bretagne S, Marmorat-Khuong A, Kuentz M, Latge JP, BartDelabesse E, Cordonnier C. Serum Aspergillus galactomannan antigen testing by sandwich ELISA: practical use in neutropenic patients. J Infect 1997; 35: 7-15.

35 Boutboul F, Alberti C, Leblanc T, et al. Invasive aspergillosis in allogeneic stem cell transplant recipients: increasing antigenemia is associated with progressive disease. Clin Infect Dis 2002; 34: 939-43.
36 Becker MJ, Lugtenburg EJ, Cornelissen IJ, Van Der Schee C, Hoogsteden HC, De Marie S. Galactomannan detection in computerized tomography-based broncho-alveolar lavage fluid and serum in haematological patients at risk for invasive pulmonary aspergillosis. Br J Haematol 2003; 121: 448-57.

37 Maertens J, Verhaegen J, Lagrou K, Van Eldere J, Boogaerts M. Screening for circulating galactomannan as a noninvasive diagnostic tool for invasive aspergillosis in prolonged neutropenic patients and stem cell transplantation recipients: a prospective validation. Blood 2001; 97: 1604-10.

38 Klont RR, Mennink-Kersten MA, Verweij PE. Utility of Aspergillus antigen detection in specimens other than serum specimens. Clin Infect Dis 2004; 39: 1467-74.

39 Stynen D, Goris A, Sarfati J, Latge JP. A new sensitive sandwich enzyme-linked immunosorbent assay to detect galactofuran in patients with invasive aspergillosis. J Clin Microbiol 1995; 33: 497-500.

40 Verweij PE, Stynen D, Rijs AJ, de Pauw BE, Hoogkamp-Korstanje JA Meis JF. Sandwich enzyme-linked immunosorbent assay compared with Pastorex latex agglutination test for diagnosing invasive aspergillosis in immunocompromised patients. J Clin Microbiol 1995; 33: 1912-14.

41 Dalle F, Lopez J, Caillot D, et al. False-positive results caused by cotton swabs in commercial Aspergillus antigen latex agglutination test. Eur J Clin Microbiol Infect Dis 2002; 21: 13032.

42 Swanink CM, Meis JF, Rijs AJ, Donnelly JP, Verweij PE. Specificity of a sandwich enzyme-linked immunosorbent assay for detecting Aspergillus galactomannan. J Clin Microbiol 1997; 35: 257-60.

43 Kappe R, Schulze-Berge A. New cause for false-positive results with the Pastorex Aspergillus antigen latex agglutination test. J Clin Microbiol 1993; 31: 2489-90.

44 Hashiguchi K, Niki Y, Soejima R. Cyclophosphamide induces falsepositive results in detection of aspergillus antigen in urine. Chest 1994; 105: 975-76.

45 Mennink-Kersten MA, Klont RR, Warris A, Op den Camp HJ, Verweij PE. Bifidobacterium lipoteichoic acid and false ELISA reactivity in aspergillus antigen detection. Lancet 2004; 363: 325-27.

46 Bennett JE, Kauffman C, Walsh T, et al. Forum report: issues in the evaluation of diagnostic tests, use of historical controls, and merits of the current multicenter collaborative groups. Clin Infect Dis 2003; 36 (suppl 3): S123-27.

47 Herbrecht R, Letscher-Bru V, Oprea C, et al. Aspergillus galactomannan detection in the diagnosis of invasive aspergillosis in cancer patients. J Clin Oncol 2002; 20: 1898-906.

48 Maertens J, Verhaegen J, Demuynck H, et al. Autopsy-controlled prospective evaluation of serial screening for circulating galactomannan by a sandwich enzyme-linked immunosorbent assay for hematological patients at risk for invasive aspergillosis. J Clin Microbiol 1999; 37: 3223-28.

49 Maertens J, Van Eldere J, Verhaegen J, Verbeken E, Verschakelen J, Boogaerts M. Use of circulating galactomannan screening for early diagnosis of invasive aspergillosis in allogeneic stem cell transplant recipients. J Infect Dis 2002; 186: 1297-306.

50 Verweij PE, Weemaes CM, Curfs JH, Bretagne S, Meis JF. Failure to detect circulating Aspergillus markers in a patient with chronic granulomatous disease and invasive aspergillosis. J Clin Microbio 2000; 38: 3900-01.

51 Husain S, Kwak EJ, Obman A, et al. Prospective assessment of Platelia Aspergillus galactomannan antigen for the diagnosis of invasive aspergillosis in lung transplant recipients. Am J Transplant 2004; 4: 796-802.

52 Kwak EJ, Husain S, Obman A, et al. Efficacy of galactomannan antigen in the Platelia Aspergillus enzyme immunoassay for diagnosis of invasive aspergillosis in liver transplant recipients. J Clin Microbiol 2004; 42: 435-38.

53 Fortun J, Martin-Davila P, Alvarez ME, et al. Aspergillus antigenemia sandwich-enzyme immunoassay test as a serodiagnostic method for invasive aspergillosis in liver transplant recipients. Transplantation 2001; 71: 145-49.

54 Marr KA, Laverdiere M, Gugel A, Leisenring W. Antifungal therapy decreases sensitivity of the Aspergillus galactomannan enzyme immunoassay. Clin Infect Dis 2005; 40: 1762-69. 
55 Maertens J, Theunissen K, Verbeken E, et al. Prospective clinical evaluation of lower cut-offs for galactomannan detection in adult neutropenic cancer patients and haematological stem cell transplant recipients. Br J Haematol 2004; 126: 852-60.

56 Siemann M, Koch-Dorfler M, Gaude M. False-positive results in premature infants with the Platelia Aspergillus sandwich enzymelinked immunosorbent assay. Mycoses 1998; 41: 373-77.

57 Ansorg R, van den Boom R, Rath PM. Detection of Aspergillus galactomannan antigen in foods and antibiotics. Mycoses 1997; 40: $353-57$

58 Viscoli C, Machetti M, Cappellano P, et al. False-positive galactomannan platelia Aspergillus test results for patients receiving piperacillin-tazobactam. Clin Infect Dis 2004; 38: 913-16.

59 Sulahian A, Touratier S, Ribaud P. False positive test for Aspergillus antigenemia related to concomitant administration of piperacillin and tazobactam. N Engl J Med 2003; 349: 2366-67.

60 Walsh TJ, Shoham S, Petraitiene R, et al. Detection of galactomannan antigenemia in patients receiving piperacillintazobactam and correlations between in vitro, in vivo, and clinical properties of the drug-antigen interaction. J Clin Microbiol 2004; 42: 4744-48.

61 Singh N, Obman A, Husain S, Aspinall S, Mietzner S, Stout JE. Reactivity of platelia Aspergillus galactomannan antigen with piperacillin-tazobactam: clinical implications based on achievable concentrations in serum. Antimicrob Agents Chemother 2004; 48: 1989-92.

62 FDA. Practice Caution in Using Bio-Rad Platelia ${ }^{\text {TM }}$ Aspergillus EIA. http://www.fda.gov/cdrh/oivd/laboratory.html\#tip8 (accessed Aug 17, 2005).

63 Pazos C, Ponton J, Del Palacio A. Contribution of (1->3)-beta-Dglucan chromogenic assay to diagnosis and therapeutic monitoring of invasive aspergillosis in neutropenic adult patients: a comparison with serial screening for circulating galactomannan. J Clin Microbiol 2005; 43: 299-305.

64 Obayashi T, Yoshida M, Mori T, et al. Plasma (1-3)-beta-D-glucan measurement in diagnosis of invasive deep mycosis and fungal febrile episodes. Lancet 1995; 345: 17-20.

65 Mori T, Ikemoto H, Matsumura M, et al. Evaluation of plasma (1-3)beta-D-glucan measurement by the kinetic turbidimetric Limulus test, for the clinical diagnosis of mycotic infections. Eur J Clin Chem Clin Biochem 1997; 35: 553-60.

66 Miyazaki T, Kohno S, Mitsutake K, et al. Plasma (1->3)-beta-Dglucan and fungal antigenemia in patients with candidemia, aspergillosis, and cryptococcosis. J Clin Microbiol 1995; 33: 3115-18.

67 Odabasi Z, Mattiuzzi G, Estey E, et al. Beta-D-glucan as a diagnostic adjunct for invasive fungal infections: validation, cutoff, development, and performance in patients with acute myelogenous luekemia and myelodysplastic syndrome. Clin Infect Dis 2004; 39: 199-205.

68 Rylander R, Norrhall M, Engdahl U, Tunsater A, Holt PG. Airways inflammation, atopy, and $(1 \longrightarrow 3)$-beta-D-glucan exposures in two schools. Am J Respir Crit Care Med 1998; 158: 1685-87.

69 Denning DW, Riniotis K, Dobrashian R, Sambatakou H. Chronic cavitary and fibrosing pulmonary and pleural aspergillosis: case series, proposed nomenclature change, and review. Clin Infect Dis 2003; 37 (suppl 3): S265-80.

70 Young RC, Bennett JE. Invasive aspergillosis. Absence of detectable antibody response. Am Rev Respir Dis 1971; 104: 710-16.

71 Chan CM, Woo PC, Leung AS, et al. Detection of antibodies specific to an antigenic cell wall galactomannoprotein for serodiagnosis of Aspergillus fumigatus aspergillosis. J Clin Microbiol 2002; 40: 2041-45.

72 Sambatakou H, Guiver M, Denning D. Pulmonary aspergillosis in a patient with chronic granulomatous disease: confirmation by polymerase chain reaction and serological tests, and successful treatment with voriconazole. Eur J Clin Microbiol Infect Dis 2003; 22: 681-85

73 Kappe R, Schulze-Berge A, Sonntag HG. Evaluation of eight antibody tests and one antigen test for the diagnosis of invasive aspergillosis. Mycoses 1996; 39: 13-23.

74 Schonheyder H. Pathogenic and serological aspects of pulmonary aspergillosis. Scand J Infect Dis Suppl 1987; 51: 1-62.
75 Centeno-Lima S, de Lacerda JM, do Carmo JA, Abecasis M, Casimiro C, Exposto F. Follow-up of anti-Aspergillus IgG and IgA antibodies in bone marrow transplanted patients with invasive aspergillosis. J Clin Lab Anal 2002; 16: 156-62.

76 Holdom MD, Lechenne B, Hay RJ, Hamilton AJ, Monod M. Production and characterization of recombinant Aspergillus fumigatus $\mathrm{Cu}, \mathrm{Zn}$ superoxide dismutase and its recognition by immune human sera. J Clin Microbiol 2000; 38: 558-62.

77 Weig M, Frosch M, Tintelnot K, et al. Use of recombinant mitogillin for improved serodiagnosis of Aspergillus fumigatusassociated diseases. I Clin Microbiol 2001; 39: 1721-30.

78 Yuen KY, Chan CM, Chan KM, et al. Characterization of AFMP1: a novel target for serodiagnosis of aspergillosis. J Clin Microbiol 2001; 39: $3830-37$.

79 Latge JP. Aspergillus fumigatus and aspergillosis. Clin Microbiol Rev 1999; 12: 310-50.

80 Strandberg GW. D-mannitol metabolism by Aspergillus candidus. J Bacteriol 1969; 97: 1305-09.

81 Wong B, Brauer KL, Tsai RR, Jayasimhulu K. Increased amounts of the Aspergillus metabolite D-mannitol in tissue and serum of rats with experimental aspergillosis. J Infect Dis 1989; 160: 95-103.

82 Lewis RE, Wiederhold NP, Chi J, et al. Detection of gliotoxin in experimental and human aspergillosis. Infect Immun 2005; 73 635-37.

83 Yoo JH, Choi JH, Choi SM, et al. Application of nucleic acid sequence-based amplification for diagnosis of and monitoring the clinical course of invasive aspergillosis in patients with hematologic diseases. Clin Infect Dis 2005; 40 392-98.

84 Loeffler J, Hebart H, Cox P, Flues N, Schumacher U, Einsele H. Nucleic acid sequence-based amplification of Aspergillus RNA in blood samples. J Clin Microbiol 2001; 39: 1626-29.

85 Bretagne S. Molecular diagnostics in clinical parasitology and mycology: limits of the current polymerase chain reaction (PCR) assays and interest of the real-time PCR assays. Clin Microbiol Infect 2003; 9: 505-11.

86 Sanguinetti M, Posteraro B, Pagano L, et al. Comparison of realtime PCR, conventional PCR, and galactomannan antigen detection by enzyme-linked immunosorbent assay using bronchoalveolar lavage fluid samples from hematology patients for diagnosis of invasive pulmonary aspergillosis. J Clin Microbiol 2003; 41: 3922-25.

87 Rantakokko-Jalava K, Laaksonen S, Issakainen J, et al. Semiquantitative detection by real-time PCR of Aspergillus fumigatus in bronchoalveolar lavage fluids and tissue biopsy specimens from patients with invasive aspergillosis. J Clin Microbiol 2003; 41: 4304-11.

88 Hendolin PH, Paulin L, Koukila-Kahkola P, et al. Panfungal PCR and multiplex liquid hybridization for detection of fungi in tissue specimens. J Clin Microbiol 2000; 38: 4186-92.

89 Willinger B, Obradovic A, Selitsch B, et al. Detection and identification of fungi from fungus balls of the maxillary sinus by molecular techniques. J Clin Microbiol 2003; 41: 581-85.

90 Paterson PJ, Seaton S, McLaughlin J, Kibbler CC. Development of molecular methods for the identification of aspergillus and emerging moulds in paraffin wax embedded tissue sections. Mo Pathol 2003; 56: 368-70.

91 Costa C, Costa JM, Desterke C, Botterel F, Cordonnier C, Bretagne S. Real-time PCR coupled with automated DNA extraction and detection of galactomannan antigen in serum by enzyme-linked immunosorbent assay for diagnosis of invasive aspergillosis. J Clin Microbiol 2002; 40: 2224-27.

92 Loeffler J, Hebart H, Brauchle U, Schumacher U, Einsele H. Comparison between plasma and whole blood specimens for detection of Aspergillus DNA by PCR. J Clin Microbiol 2000; 38: 3830-33.

93 Garcia ME, Blanco JL, Caballero J, Gargallo-Viola D. Anticoagulants interfere with PCR used to diagnose invasive aspergillosis. J Clin Microbiol 2002; 40: 1567-68.

94 Loffler J, Hebart H, Schumacher U, Reitze H, Einsele H. Comparison of different methods for extraction of DNA of fungal pathogens from cultures and blood. J Clin Microbiol 1997; 35: 3311-12. 
95 Muller FM, Werner KE, Kasai M, Francesconi A, Chanock SJ, Walsh TJ. Rapid extraction of genomic DNA from medically important yeasts and filamentous fungi by high-speed cell disruption. J Clin Microbiol 1998; 36: 1625-29.

96 Loeffler J, Hebart H, Bialek R, et al. Contaminations occurring in fungal PCR assays. J Clin Microbiol 1999; 37: 1200-02.

97 Nierman W, Pain A, Anderson MJ, et al. Genomic sequence of the pathogenic and allergenic Aspergillus fumigatus. Nature (in press).

98 Chen SC, Halliday CL, Meyer W. A review of nucleic acid-based diagnostic tests for systemic mycoses with an emphasis on polymerase chain reaction-based assays. Med Mycol 2002; 40: 333-57.

99 Spiess B, Buchheidt D, Baust C, et al. Development of a LightCycler PCR assay for detection and quantification of Aspergillus fumigatus DNA in clinical samples from neutropenic patients. J Clin Microbiol 2003; 41: 1811-18.

100 Melchers WJ, Verweij PE, van den Hurk P, et al. General primermediated PCR for detection of Aspergillus species. J Clin Microbiol 1994; 32: 1710-17.

101 Spreadbury C, Holden D, Aufauvre-Brown A, Bainbridge B, Cohen J. Detection of Aspergillus fumigatus by polymerase chain reaction. J Clin Microbiol 1993; 31: 615-21.

102 Walsh TJ, Francesconi A, Kasai M, Chanock SJ. PCR and singlestrand conformational polymorphism for recognition of medically important opportunistic fungi. J Clin Microbiol 1995; 33: 3216-20.

103 Rath PM, Ansorg R. Identification of medically important Aspergillus species by single strand conformational polymorphism (SSCP) of the PCR-amplified intergenic spacer region. Mycoses 2000; 43: 381-86.

104 Hopfer RL, Walden P, Setterquist S, Highsmith WE. Detection and differentiation of fungi in clinical specimens using polymerase chain reaction (PCR) amplification and restriction enzyme analysis. $J$ Med Vet Mycol 1993; 31: 65-75.

105 Martin C, Roberts D, van Der Weide M, et al. Development of a PCRbased line probe assay for identification of fungal pathogens. J Clin Microbiol 2000; 38: 3735-42.

106 Turenne CY, Sanche SE, Hoban DJ, Karlowsky JA, Kabani AM. Rapid identification of fungi by using the ITS2 genetic region and an automated fluorescent capillary electrophoresis system. J Clin Microbiol 1999; 37: 1846-51.

107 de Aguirre L, Hurst SF, Choi JS, Shin JH, Hinrikson HP, Morrison CJ. Rapid differentiation of Aspergillus species from other medically important opportunistic molds and yeasts by PCR-enzyme immunoassay. J Clin Microbiol 2004; 42: 3495-504.

108 Forbes BA. Introducing a molecular test into the clinical microbiology laboratory: development, evaluation, and validation. Arch Pathol Lab Med 2003; 127: 1106-11.

109 Dimech W, Bowden S, Brestovac B, et al. Validation of assembled nucleic acid-based tests in diagnostic microbiology laboratories. Pathology 2004; 36: 45-50.

110 Einsele H, Hebart H, Roller G, et al. Detection and identification of fungal pathogens in blood by using molecular probes. $\mathrm{J}$ Clin Microbiol 1997; 35: 1353-60.

111 Kami M, Fukui T, Ogawa S, et al. Use of real-time PCR on blood samples for diagnosis of invasive aspergillosis. Clin Infect Dis 2001; 33: 1504-12.

112 Bretagne S, Costa JM, Marmorat-Khuong A, et al. Detection of Aspergillus species DNA in bronchoalveolar lavage samples by competitive PCR. J Clin Microbiol 1995; 33: 1164-68.

113 Bretagne S, Costa JM, Bart-Delabesse E, Dhedin N, Rieux C, Cordonnier C. Comparison of serum galactomannan antigen detection and competitive polymerase chain reaction for diagnosing invasive aspergillosis. Clin Infect Dis 1998; 26: 1407-12.

114 Verweij PE, Meis JF, van den Hurk P, Zoll J, Samson RA, Melchers WJ. Phylogenetic relationships of five species of Aspergillus and related taxa as deduced by comparison of sequences of small subunit ribosomal RNA. J Med Vet MYcol 1995; 33: 185-90.
115 O'Sullivan CE, Kasai M, Francesconi A, et al. Development and validation of a quantitative real-time PCR assay using fluorescence resonance energy transfer technology for detection of Aspergillus fumigatus in experimental invasive pulmonary aspergillosis. J Clin Microbiol 2003; 41: 5676-82.

116 Bowman JC, Abruzzo GK, Anderson JW, et al. Quantitative PCR assay to measure Aspergillus fumigatus burden in a murine model of disseminated aspergillosis: demonstration of efficacy of caspofungin acetate. Antimicrob Agents Chemother 2001; 45: 3474-81.

117 Henry T, Iwen PC, Hinrichs SH. Identification of Aspergillus species using internal transcribed spacer regions 1 and 2. J Clin Microbio 2000; 38: 1510-15.

118 Luo G, Mitchell TG. Rapid identification of pathogenic fungi directly from cultures by using multiplex PCR. J Clin Microbiol 2002; 40: 2860-65.

119 Zhao J, Kong F, Li R, Wang X, Wan Z, Wang D. Identification of Aspergillus fumigatus and related species by nested PCR targeting ribosomal DNA internal transcribed spacer regions. J Clin Microbiol 2001; 39: 2261-66.

120 Herbrecht R, Denning DW, Patterson TF, et al. Voriconazole versus amphotericin B for primary therapy of invasive aspergillosis. $N$ Engl $J$ Med 2002; 347: 408-15.

121 Loeffler J, Kloepfer K, Hebart H, et al. Polymerase chain reaction detection of aspergillus DNA in experimental models of invasive aspergillosis. J Infect Dis 2002; 185: 1203-06.

122 Albelda SM, Talbot GH, Gerson SL, Miller WT, Cassileth PA. Role of fiberoptic bronchoscopy in the diagnosis of invasive pulmonary aspergillosis in patients with acute leukemia. Am J Med 1984; 76: 1027-34.

123 Kahn FW, Jones JM, England DM. The role of bronchoalveolar lavage in the diagnosis of invasive pulmonary aspergillosis. Am J Clin Pathol 1986; 86: 518-23.

124 Einsele H, Quabeck K, Muller KD, et al. Prediction of invasive pulmonary aspergillosis from colonisation of lower respiratory tract before marrow transplantation. Lancet 1998; 352: 1443.

125 Levy H, Horak DA, Tegtmeier BR, Yokota SB, Forman SJ. The value of bronchoalveolar lavage and bronchial washings in the diagnosis of invasive pulmonary aspergillosis. Respir Med 1992; 86: 243-48.

126 von Eiff M, Zuhlsdorf M, Roos N, Hesse M, Schulten R, van de Loo J. Pulmonary fungal infections in patients with hematological malignancies-diagnostic approaches. Ann Hematol 1995; 70: 135-41.

127 Crystal RG, Reynolds HY, Kalica AR. Bronchoalveolar lavage. The report of an international conference. Chest 1986; 90: 122-31.

128 McWhinney PH, Kibbler CC, Hamon MD, et al. Progress in the diagnosis and management of aspergillosis in bone marrow transplantation: 13 years' experience. Clin Infect Dis 1993; 17: 397-404.

129 Brown MJ, Worthy SA, Flint JD, Muller NL. Invasive aspergillosis in the immunocompromised host: utility of computed tomography and bronchoalveolar lavage. Clin Radiol 1998; 53: 255-57.

130 Musher B, Fredricks D, Leisenring W, Balajee SA, Smith C, Marr KA. Aspergillus galactomannan enzyme immunoassay and quantitative PCR for diagnosis of invasive aspergillosis with bronchoalveolar lavage fluid. J Clin Microbiol 2004; 42: 5517-22.

$131 \mathrm{Yu}$ VL, Muder RR, Poorsattar A. Significance of isolation of Aspergillus from the respiratory tract in diagnosis of invasive pulmonary aspergillosis. Results from a three-year prospective study. Am J Med 1986; 81: 249-54.

132 Hebart H, Loffler J, Meisner C, et al. Early detection of Aspergillus infection after allogeneic stem cell transplantation by polymerase chain reaction screening. J Infect Dis 2000; 181: 1713-19.

133 Jones BL, McLintock LA. Impact of diagnostic markers on early antifungal therapy. Curr Opin Infect Dis 2003; 16: 521-26. 